This is the author accepted manuscript of the published article

Hessel, G. (2020). Overall L2 proficiency maintenance and development among returning ERASMUS study abroad participants, Study Abroad Research in Second Language Acquisition and International Education, 5(1), 119-152, accessible here:

https://doi.org/10.1075/sar

This article is under copyright and the publisher must be contacted for permission to re-use or reprint the material in any form.

\title{
Overall L2 proficiency maintenance and development among returning ERASMUS study abroad participants
}

\section{Gianna Hessel}

University of Graz

This study examines the sustainability of gains in overall English proficiency made by 81 German students on ERASMUS study abroad placements in the UK (lasting one term or one academic year) following their return to their home country. Students were tracked using Ctests and questionnaires from pre-study abroad up until nine months post-return. Their development was compared with that of 25 peers who applied for ERASMUS placements, but continued studying at home. The analysis presented focuses on the post-return phase and includes factors associated with individual differences in L2 proficiency development postreturn, self-perceived L2 skills development, and returnees' perceived needs regarding further language classes. Results show that students tended to sustain gains in overall L2 proficiency made during study abroad. L2 proficiency level achieved by the end of study abroad, selfefficacy in using the L2 in social interactions, and majoring in English were all positively associated with post-return L2 development.

Keywords: post-return; L2 proficiency; advanced learners; English as a foreign language (EFL) 


\section{Introduction}

The promotion of student mobility forms a key objective of European higher education policy and features prominently in the internationalization strategies of higher education institutions in the EU member states (Engel, Sandstrom, Van der Aa, \& Glass, 2015). As a consequence, the European Action Scheme for the Mobility of University Students (ERASMUS), which in 2014 became part of ERASMUS+, has developed into the world's largest mobility programme for university students and staff, funding more than 300,000 student exchanges per year. One of the programme's key learning objectives is “improved foreign language competences" (European Commission, 2014, p. 31). Given the significance, scale and intended growth of temporary student mobility across Europe, it is important for research to develop a better understanding of the foreign language (L2) learning outcomes of ERASMUS study abroad and their sustainability after students' return to the home country.

While there is a growing body of research on the immediate linguistic outcomes of participation in ERASMUS (larger longitudinal studies include, e.g., Hessel \& Vanderplank, 2018; Mitchell, McManus \& Tracy-Ventura, 2017; Pérez-Vidal, 2014; Rees \& Klapper, 2007), studies that investigate how L2 proficiency gains made by ERASMUS students are maintained and further developed upon return to the home country remain extremely scarce. This is presumably because investigating the sustainability of study abroad outcomes requires resource-intensive longitudinal studies that track student development during study abroad and for any length of time after the students return. Ideally, this would include a suitable comparison group in order to discern development that is attributable to participation in study abroad from learning that may occur over time regardless of the learning context, establishing the observed effects as actual longer term effects of having studied abroad. Against this background, it is less surprising perhaps that despite the enormous scale of the ERASMUS study abroad programme, the question of how returning ERASMUS students maintain and 
further develop L2 proficiency gains made during study abroad has received so little scholarly attention. And yet, studies in this area are also needed to inform the design of learning programmes that seek to support returning ERASMUS students in further developing their L2 skills in an independent manner and/or in instructional settings.

The present study investigates how ERASMUS students participating in study abroad programmes for one term or one academic year maintain and further develop their overall L2 proficiency levels when they resume their degree studies in the home country. Their L2 proficiency development post-return is compared with that of their peers who had applied for an ERASMUS placement, but continued studying at home. While the focus of this study is clearly on the L2 proficiency development of the returning students, the comparison group of ERASMUS applicants serves to distinguish the longer term effects of participation in study abroad from development related to mere participant maturation, time and study effects.

\section{Literature review}

\section{Research on L2 development post-study abroad}

There is a small body of research that has investigated L2 development among returning study abroad participants in a variety of areas, including general oral proficiency (Huensch, Tracy-Ventura, Bridges, \& Cuesta Medina, 2019; Mehotcheva, 2010), oral accuracy (Howard, 2009; Juan-Garau, 2014; Regan, 2005), oral fluency (Huensch et al., 2019; Huensch \& TracyVentura, 2017; Mehotcheva, 2010), listening comprehension (Beattie, Valls-Ferrer, \& PérezVidal, 2014), academic and general writing skills (complexity, fluency, accuracy) (Llanes, 2012; Pérez-Vidal \& Barquin, 2014; Pérez-Vidal \& Juan-Garau, 2009; Sasaki, 2009), lexical development (Kubota, 2017; Pizziconi, 2017), and overall L2 proficiency (Juan-Garau, Salazar-Noguera, \& Prieto-Arranz, 2014; Mehotcheva, 2010). 
In the European study abroad context, initial case study work by Howard (2009) and Regan (2005) investigated the retention of oral French language skills among Irish university students studying French, one year after their return from a year abroad in France. Regan (2005) found that the 'native-like' pattern of deleting the ne particle in French negation was largely maintained by her five participants during the year following their return, while Howard (2009) reports both attriting (e.g., accuracy) and stable features (e.g., 'native-like' use of present tense to refer to the past) in the speech produced by his case study participant. Mehotcheva (2010) also includes a longitudinal multiple case study, in which she tracked the overall and oral L2 proficiency development of five university students from Germany and the Netherlands with a variety of measures over a period of twelve months after studying or interning through ERASMUS in Spain for five to seven months. While there were pronounced individual differences in post-SA L2 development between the five individuals, she observed most stability in students' overall L2 proficiency levels, as measured by a C-test, while the most consistent indications of attrition occurred in the students' oral speech production (i.e., increases in disfluency markers, pseudo words, and decreasing lexical diversity) at twelve months post-return. The author interprets these as manifestations of reduced lexical access owing to attrition, which is further supported by the observed increase in reaction times in a picture-naming task. These case studies have provided fine-grained analyses of participants' post-return L2 development, mostly in the oral domain. Naturally, they cannot ascertain whether the observed developmental patterns are highly idiosyncratic or whether they represent a more general trend among the returning cohort.

As the first larger longitudinal study, Pérez-Vidal and Juan-Garau (2009) examined the L2 writing skills of 37 early bilingual Spanish-Catalan university students in an English translation and interpreting degree programme at 15 months post-return from study abroad in the UK. They report non-significant declining trends in several markers of fluency and lexical 
diversity in the students' writing during this period, despite additional English language classes students received post-study abroad. Pérez-Vidal (2014) then published a larger body of studies that examined development in a variety of linguistic features post-return as part of the substantial SALA (Study Abroad and Language Acquisition) project, based on the same population of early bilingual Spanish-Catalan students. This project involved 57 students, whose English language skills, attitudes and motivation relating to learning English, and intercultural awareness were measured 1) upon entry into the university programme, 2) after six months (two terms) at the home university / pre-study abroad, 3) upon return from the obligatory three-month ERASMUS study abroad semester in the UK, and 4) 15 months postreturn. In terms of the students' linguistic development, the researchers found that 15 months after their return from study abroad and an additional 80 hours of English language instruction, the students tended to maintain the gains in overall English language proficiency measured with a Cloze test (Juan-Garau, Salazar-Noguera, \& Prieto-Arranz, 2014), in listening comprehension (Beattie, Valls-Ferrer, \& Pérez-Vidal, 2014), accuracy and fluency in speaking (Juan-Garau, 2014; Valls-Ferrer \& Mora, 2014), as well as the gains in fluency and complexity in writing (Pérez-Vidal \& Barquin, 2014) that they had made abroad.

As part of the comprehensive LANGSNAP project (Mitchell, Tracy-Ventura, \& McManus, 2017), Huensch et al. (2019) examined retention of oral proficiency and speech fluency in 17 French L2 and 14 Spanish L2 Modern Foreign Languages (MFL) students with L1 English four years after their return from the compulsory third year abroad, which was either spent on a student exchange, teaching assistantship, or workplace internship. The researchers examined development in utterance fluency (speed, breakdown and repair fluency) and general oral proficiency. They found that students of Spanish and French both tended to maintain the gains in fluency and oral proficiency they had made abroad four years post-return, and three years after their degree studies and L2 instruction had ended. Moreover, 
students who were classified as having 'intense L2 contact' post-return (e.g., who continued to use French at work, lived with French speakers, or went on further stays abroad) tended to show further progress in oral L2 proficiency four years post-SA.

In summary, the majority of studies to date find successful maintenance in some or all areas of L2 knowledge and skills over post-return observation periods of 12-15 months (but see Huensch et al., 2019, who observe maintainance of oral proficiency and speech fluency over a period of 48 months). Three studies observe continued progress in the areas of lexicogrammatical competence (Juan -Garau, Salazar-Noguera, \& Prieto-Arranz, 2014), lexical knowledge (Kubota, 2017), and overall oral proficiency (Huensch et al., 2019). Five studies report attrition to some degree, in oral fluency (Huensch \& Tracy-Ventura, 2017; Mehotcheva, 2010), accuracy in writing (Llanes, 2012; Pérez-Vidal \& Juan-Garau, 2009) and speech (Howard, 2009), and lexical diversity in speech (Mehotcheva, 2010). Since effect sizes are not commonly reported, it is difficult to establish the extent of post-return attrition/ progress made, or draw comparisons between studies.

Most significantly perhaps, one needs to note that the observed trend toward successful L2 maintenance post-study abroad is largely (except Llanes, 2012; Mehotcheva, 2010) based on research involving MFL students who chose to study the L2 at degree-level and who continued to attend language classes during the post-return observation period. The contribution of instruction itself remains unclear as it was compulsory for the MFL students observed. While studying this student group is clearly important given the significance of L2 proficiency in their professional development, it remains unclear to what extent post-return L2 development observed among MFL students may be generalizable to the wider ERASMUS student population.

Research on factors associated with individual differences in L2 development post-SA 
To date, very little is known about factors associated with individual differences in post-return L2 development. Only two fairly recent studies have included an analysis of such factors among their research questions. The above-mentioned study by Huensch et al. (2019) investigated the role of 'proficiency level attained by the end of study abroad' and 'continued L2 contact post-return' in the maintenance of students' oral fluency and overall oral proficiency four years post-return from the year abroad. Higher pre-return L2 proficiency levels were associated with better maintenance of overall oral proficiency and repair fluency (number of corrections), while continued L2 contact / usage during the four years was associated with better maintenance of speed fluency, breakdown fluency, and overall oral proficiency. Based on the observed effect sizes, the researchers conclude that L2 proficiency achieved by the end of SA may have the greater impact on the maintenance of general oral proficiency than continued L2 contact.

Mehotcheva (2010) investigated a number of participant-related factors, including prereturn proficiency, continued L2 contact, and L2 attitudes and motivation in relation to maintenance of overall L2 proficiency and oral proficiency among German and Dutch ERASMUS students who had studied or interned in Spain for five to seven months. She reports that higher pre-return L2 proficiency levels were associated with higher lexical diversity, fewer filled pauses, false starts, corrections and other foreign language words in the students' speech, as well as faster reaction times in the picture-naming task (faster lexical access). Positive attitudes towards the L2, L2 learning and the L2 community, and a stronger integrative orientation were associated with less filled pauses, while stronger instrumental orientation was associated with higher overall L2 proficiency levels (C-test results) at postreturn. Self-reported continued L2 contact, on the other hand, was not related to any linguistic outcomes. Mehotcheva's findings on individual differences need to be interpreted cautiously as they are extrapolated from the cross-sectional part of her study. For example, students' pre- 
return proficiency levels were established retrospectively with self-assessment scales, rather than longitudinally at pre-return and post-return.

\section{Purpose of the present study}

The present study is the first larger longitudinal study to investigate overall L2 proficiency development among returning ERASMUS students who study a variety of academic subjects and are not necessarily majoring in MFL. It also examines factors associated with individual differences in post-return L2 proficiency development, including pre-return L2 proficiency level and continued L2 contact / usage, as these have been foregrounded in the literature. In addition, academic subject background (majoring in the L2 vs. another subject) and gender will be investigated as individual differences factors since almost all of the existing studies on post-return L2 development are based on MFL students, mostly female. Thus, examining their involvement in post-return L2 development is important with regard to the generalizability of findings to both genders and to ERASMUS students studying other subjects. In addition, the study examines self-efficacy in using the L2 in social interactions (i.e., students' beliefs about their ability to converse in the L2) as a factor in postreturn L2 proficiency development. Self-efficacy is a well-researched psychological construct and a central component of Bandura's social cognitive theory (SCT) (Bandura, 1986). Simply put, it denotes an individual's beliefs about what they are able to do in a given skill domain (ibid.). SCT would predict that students with higher levels of self-efficacy in using the L2 in social interactions (i.e., those who feel more able to converse in the L2) would be more likely to engage in such opportunities. As opportunities for conversing in the L2 are conceivably less abundant back in the home country and often not necessary, it is hypothesized that students who are more willing to take up such opportunities may be at a developmental advantage. Self-efficacy in using the L2 in social interactions had previously emerged as a key predictor of engagement in L2-mediated interactions (Hessel, 2019) and overall L2 
proficiency development during study abroad with the same population of students (Hessel, 2017).

Lastly, the present study will examine the role of length of stay (i.e., duration of study abroad) in relation to post-return L2 development. LoS has been shown to affect the extent of linguistic gains made during study abroad in a variety of areas of L2 knowledge and skills (e.g., Hessel \& Vanderplank, 2018; Davidson, 2010; Ife, Vives, \& Meara, 2000; Llanes \& Muñoz, 2009; Sasaki, 2009; Sax, 2003; Vande Berg, Connor-Linton, \& Paige, 2009). However, its impact on SA participants' continued L2 development post-study abroad remains hitherto unexamined. Thus, the present study investigates post-return L2 development among students who studied abroad for one term and one academic year. In addition, a comparison group is included to distinguish the longer term effects of participation in ERASMUS study abroad from development related to mere participant maturation, time and study effects.

The following research questions guided the study:

RQ 1: How do the overall L2 proficiency levels of students who studied abroad for one academic year (SA group 1) or one academic term (SA group 2) develop after their return to the home country, and how does their post-return development compare to that of peers who had applied for an ERASMUS placement but continued to study at home (AH group)?

RQ 2: How do students' self-assessments of their L2 skills develop within SA group 1, SA group 2 and the AH group?

RQ 3: What participant-related factors may be associated with individual differences in overall L2 proficiency development post-SA? 
RQ 4: What are the returning ERASMUS students' perceived needs and interests regarding language classes for further developing their L2 skills?

\section{Method}

\subsection{Overall study design}

The post-return study forms part of a larger research project that examined the overall L2 proficiency development, evolving L2 motivation and intercultural learning of German university students who participated in ERASMUS study abroad programmes in the UK for one term or one academic year. The students were tracked from the point of their departure to the UK up until nine months post-return, and their development compared to students of the same cohort who had applied for an ERASMUS study placement in the UK, but continued to study in Germany (see participant section 3.2). As shown in Table 1, students in all groups completed baseline / pre-departure questionnaires and C-tests in September 2012. Students in study abroad (SA) group 1 (studying abroad for one academic year) completed an inprogramme questionnaire and C-test after their first term abroad (December 2012), a prereturn questionnaire and C-test after a further six months abroad (late June 2013), and a postreturn questionnaire and C-test, nine months after their return to the home country (late March 2014). Students in the at-home (AH) group followed the exact same procedure, completing the questionnaires and C-tests in September 2012, December 2012, June 2013 and March 2014. Students in SA group 2 (studying abroad for one term only) completed their pre-return questionnaire and C-test at the end of their term abroad (December 2012), and their postreturn questionnaire and C-test after six months in the home country (late June 2013).

Table 1. Overview of data collection points in the larger study

\begin{tabular}{lllll}
\hline & September & December & June & March \\
& $\begin{array}{l}\text { Questionnaire } \\
+ \text { C-test }\end{array}$ & $\begin{array}{l}\text { Questionnaire } \\
+ \text { C-test }\end{array}$ & $\begin{array}{l}\text { Questionnaire } \\
+ \text { C-test }\end{array}$ & $\begin{array}{l}\text { Questionnaire } \\
+ \text { C-test }\end{array}$ \\
& pre-departure & in-programme & pre-return & post-return \\
& +3 months & +6 months & +9 months \\
\hline \multirow{2}{*}{ SA group 1 } & +0 months & +3 . & & \\
\hline
\end{tabular}




\begin{tabular}{lllll}
\hline \multirow{2}{*}{ SA group 2 } & pre-departure & pre-return & post-return & \\
& +0 months & +3 months & +6 months & \\
\hline \multirow{2}{*}{ AH group } & baseline & in-study & in-study & End of study \\
& +0 months & +3 months & +6 months & +9 months \\
\hline
\end{tabular}

\subsection{Participants}

The participants were $106 \mathrm{~L} 1$ German-speaking university students studying a variety of academic subjects at over 30 different universities in Germany. All students had applied for ERASMUS exchanges with UK partner institutions during the academic year 2012-13. Of the 106 participants recruited, 40 students then studied abroad in the UK for one academic year (SA group 1), 41 students studied abroad for one term (SA group 2), while 25 students were ERASMUS applicants to the UK in the same cohort who had either been unsuccessful in securing a placement, or had withdrawn their application and continued their studies in Germany throughout the study period. Study abroad applicants or 'potentially mobile students' were chosen as a comparison group as they can be considered to be more comparable to study abroad participants than students with no intention of studying abroad, most importantly perhaps in their willingness and confidence to live and study through the L2 (Van Mol \& Timmerman, 2014). The ratio of ERASMUS applicants to study placements in the UK tends to be particularly high (possibility to study through English, improve English skills, perceived quality of the higher education system), which tends to result in a pool of rejected applicants. The selection criteria for ERASMUS placements were not standardized across German higher education institutions at the time, which contributed to reducing the systematic variation between successful and unsuccessful applicants. 
Table 2. Comparison of participant background characteristics at baseline (pre-study abroad)

\begin{tabular}{|c|c|c|c|c|}
\hline Variable & SA group 1 & SA group 2 & AH group & Between-group diff. \\
\hline $\mathrm{N}$ & 40 & 41 & 25 & \\
\hline Age & $22.16(S D=1.30)$ & $22.22(S D=1.36)$ & $22.08(S D=2.42)$ & $F(2,98)=.63, p=.563$ \\
\hline Gender [male/fem.] & $\begin{array}{c}7(17.5 \%) / \\
32(80.0 \%) \\
\text { (1 (2.5\%) unspecified) } \\
\end{array}$ & $\begin{array}{c}14(34.1 \%) / \\
25(61.0 \%) \\
(2(4.9 \%) \text { unspecified }) \\
\end{array}$ & $\begin{array}{l}5(20.0 \%) / \\
20(80.0 \%)\end{array}$ & $\chi^{2}(2)=3.81, p=.149$ \\
\hline $\begin{array}{l}\text { No. of terms studied } \\
\text { before participating in } \\
\text { ERASMUS }\end{array}$ & $4.63(S D=1.72)$ & $4.11(S D=1.27)$ & $4.72(S D=2.46)$ & $F(2,98)=1.19, p=.310$ \\
\hline $\begin{array}{l}\text { Academic achievement [as } \\
\text { self-reported GPA: } 1-6]^{*}\end{array}$ & $2.07(S D=0.50)$ & $1.90(S D=0.53)$ & $1.86(S D=0.43)$ & $F(2,90)=1.50, p=.229$ \\
\hline $\begin{array}{l}\text { Academic subjects studied } \\
\text { by the participants }\end{array}$ & $\begin{array}{c}\text { Social Sciences, } \\
\text { Business and Law: } \\
18(45.0 \%), \\
\text { Arts and Humanities: } \\
10(25.0 \%), \\
\text { Natural Sciences, } \\
\text { Mathematics and } \\
\text { Computer Science: } \\
5(12.5 \%), \\
\text { Education: } 6(15 \%), \\
\text { (unspec.: } 1[2.5 \%])\end{array}$ & $\begin{array}{c}\text { Social Sciences, } \\
\text { Business and Law: } \\
16(39.0 \%), \\
\text { Arts and Humanities: } \\
7(17.1 \%), \\
\text { Natural Sciences, } \\
\text { Mathematics and } \\
\text { Computer Science: } \\
7(17.1 \%), \\
\text { Education: } 8(19.5 \%), \\
\text { (unspec.: } 3[7.3 \%])\end{array}$ & $\begin{array}{c}\text { Social Sciences, } \\
\text { Business and Law: } \\
11(44.0 \%), \\
\text { Arts and Humanities: } \\
9(36.0 \%), \\
\text { Education: } 5(20.0 \%)\end{array}$ & $\chi^{2}(12)=2.69, p=.547$ \\
\hline $\begin{array}{l}\text { Of whom majoring in } \\
\text { English (incl. teaching } \\
\text { degrees) }\end{array}$ & $14(35.0 \%)$ & $10(24.4 \%)$ & $7(28.0 \%)$ & $\chi^{2}(2)=4.06, p=.131$ \\
\hline
\end{tabular}

* Prior academic achievement according to a grading scale from 1 to 6, where 1 marks the top end.

Table 2 shows the participant background characteristics of students within the three groups. A gender imbalance towards female students applied to all groups. Upon entry into the study, most participants had completed their second year (four terms) at university with good success. ${ }^{1}$ Students of the Social Sciences were most highly represented in all groups, followed by students in the Arts and Humanities, Natural Sciences and Education (the comparison group had lost all natural scientists by the time of the post-return collection). There was a significant and fairly balanced proportion of English majors in each group. Importantly in this respect, a stay abroad does not constitute a compulsory part of the MFL curriculum at state-funded universities in Germany, but rather a personal choice (subject to successful competition for a placement). While MFL curricula vary between universities, students tend to complete the 'language foundation courses' (focusing, for example, on grammar, pronunciation, writing skills, etc.) within the first two years of their degree. The

\footnotetext{
${ }^{1}$ An average GPA of 2 literally translates into gut (good), while an average of 1 would be sebr gut (very good), and 3 befriedigend (satisfactory).
} 
advanced years emphasise Seminare (seminars), which focus on the discipline (e.g., literature, linguistics, or pedagogy) and on developing basic research skills. This explains how it is possible that most of the English majors in this study did not attend any formal English language instruction upon return from SA, although they continued to be exposed to English language content in other classes. Students in all three groups had learned English for eight to nine years at school and an average of two terms of English language instruction of some sort at university upon entry into the study. Their overall English language proficiency level was upper-intermediate to advanced, which was established in the C-test at baseline (see 'instruments') and students' self-reported IELTS / TOEFL / CAE test scores. All participants were required to be German L1 speakers.

\subsection{Instruments}

\subsubsection{The C-test}

In order to establish development in the students' overall L2 proficiency levels, a C-test (Raatz \& Klein-Braley, 1982) was used at pre- and post-return. In over 30 years of validation research, C-tests have been found to be highly reliable measures of general (or 'overall') language proficiency that tap most strongly into lexico-grammatical competence, but also correlate well with discrete tests of L2 skills, including L2 listening and speaking, probably because they implicate lexico-grammatical competence (Asano, 2014; Babaii \& Ansary, 2001; Dörnyei \& Katona, 1992; Eckes \& Grotjahn, 2006; Grotjahn, 2010, 2014; Singleton \& Singleton, 2002). C-tests have been used in a wide variety of practical L2 testing and research contexts, including study abroad research (e.g., Coleman, 1996; Mehotcheva, 2010; Rees \& Klapper, 2007). A major advantage of employing C-tests is that they are a well-tried, highly reliable and valid measure of general L2 proficiency that tends to be more economical to administer and score than alternative test batteries. This is particularly important for studies that investigate multiple related aspects of student learning, as was the case in the present 
study. The major disadvantage of employing C-tests is that they do not allow for a differentiated examination of L2 knowledge and skills.

The C-test employed consisted of five short texts on non-specialist topics, which were taken from scientific magazines and quality newspapers (see Appendix A). The test had 100 gaps in total, which were coded dichotomously as correct / incorrect, resulting in a range of possible test scores from zero to 100. A reconstructed word was scored as correct if it was grammatically correct, without spelling mistakes and meaningful in the context of the propositional content of the sentence. Four of the texts were advanced level texts which had been extensively validated in attrition research with English L1 speakers (e.g., Keijzer, 2007), with an expected score of 87-90 for educated non-attrited L1 speakers. These more difficult texts were chosen in order to prevent ceiling effects with the advanced EFL learners in the study. These four texts were complemented by one slightly easier text, which had previously been used and validated by Khabbazbashi (2013) with intermediate to advanced EFL learners. All five texts were validated in a pilot study with German university students with and without study abroad experience, and with L1 English-speaking university students. The same set of texts was administered across all data collection points and groups (average Cronbach's alpha $=.90)$. The C-test formed the last content page of the questionnaire to prevent response bias in the questionnaire items as a result of the testing experience.

\subsubsection{The questionnaires}

All questionnaires were hosted by 'SoSci Survey’ (Leiner, 2019). They were completed anonymously and in German. With particular relevance to the analysis below, the pre- and post-return questionnaires ${ }^{2}$ contained closed- and open-ended items that inquired into the students' self-perceived L2 skills in informal and academic contexts (Cronbach's alpha = .93; eight-item scale, shown in Figure 1), their self-efficacy in using the L2 in social interactions

\footnotetext{
${ }^{2}$ The baseline/ pre-departure and in-programme questionnaires of the larger study are described in Hessel (2016)
} 
(Cronbach's alpha $=.90 ; 17$-item scale included in Appendix B), students' continued L2 contact / usage in their free time and as part of their academic work (four items, detailed in results section 4.3), and students' perceived needs and interests regarding further English language classes (open-ended item allowing for verbal response, detailed in results section 4.4). The verbal data on the students' perceived needs and interests regarding further English language instruction were analyzed according to the procedures for qualitative content analysis detailed in Kuckartz (2012).

Figure 1. Self-assessed L2 skills

Please rate your English language skills in
the following contexts:
Reading academic texts
Academic writing
Listening in academic contexts
Speaking in academic contexts
Reading for pleasure
Informal writing
Listening in informal conversations
Speaking in informal conversations

\begin{tabular}{ccccccc} 
very limited & \multicolumn{3}{r}{} & \multicolumn{2}{r}{ excellent } \\
\hline 1 & 2 & 3 & 4 & 5 & 6 & 7 \\
0 & 0 & 0 & 0 & 0 & 0 & 0 \\
0 & 0 & 0 & 0 & 0 & 0 & 0 \\
0 & 0 & 0 & 0 & 0 & 0 & 0 \\
0 & 0 & 0 & 0 & 0 & 0 & 0 \\
0 & 0 & 0 & 0 & 0 & 0 & 0 \\
0 & 0 & 0 & 0 & 0 & 0 & 0 \\
0 & 0 & 0 & 0 & 0 & 0 & 0 \\
0 & 0 & 0 & 0 & 0 & 0 & 0
\end{tabular}

\subsection{Procedures of data collection and analysis}

At each data collection point, the participants accessed the online C-test and questionnaire anonymously with a personalized link that was emailed directly by the online survey host 'SoSci Survey'. The first questionnaire was preceded by a consent form which detailed the conditions of participation, and the processing and storage of data. The participant data were imported directly into SPSS 25 for descriptive and inferential statistical analysis. Overall L2 proficiency development and changes in self-assessed L2 proficiency during the post-return phase were established using paired samples t-tests. Multiple regression analysis served to identify factors associated with individual differences in overall L2 proficiency development post-return. In this analysis, L2 proficiency gain during the post-return phase (post-return score - pre-return score) formed the dependent variable and the participant-related factors 
formed the independent (or 'predictor') variables. The assumptions underlying multiple regression modelling were tested according to the procedures proposed in Field (2013). The distribution of scores for some variables deviated from normal. A bootstrapping procedure (Efron \& Tibshirani, 1993) with bias-corrected and accelerated (BCa) 95\% confidence intervals was applied to all tests involving non-normally distributed data to control for bias that may result from the non-normal sampling distribution. As noted, the open-ended questionnaire data on the students' perceived needs and interests regarding further English language classes were analyzed according to the procedures for qualitative content analysis described in Kuckartz (2012).

\section{Results}

\subsection{Students' overall L2 proficiency development post-return}

Table 3 shows the students' C-test raw and gain scores at baseline / pre-departure, during the SA period, at the end of the SA period (pre-return), during the post-return period, and at the end of the post-return period. The students' overall L2 proficiency gains during study abroad are summarized to contextualize the analysis of their sustainability post-return.

Table 3. C-test raw and gain scores (means and standard deviations)

\begin{tabular}{|c|c|c|c|c|c|}
\hline & $\begin{array}{c}\text { Baseline / } \\
\text { pre-SA score }\end{array}$ & $\begin{array}{l}\text { SA period } \\
\text { gain score }\end{array}$ & $\begin{array}{c}\text { end-of-SA phase } \\
\text { score }\end{array}$ & $\begin{array}{l}\text { PR period } \\
\text { gain score }\end{array}$ & $\begin{array}{c}\text { end-of-PR phase } \\
\text { score }\end{array}$ \\
\hline SA group 1 & $\begin{array}{c}67.07 \\
(S D=13.30) \\
\text { at }+0 \text { months }\end{array}$ & $\begin{array}{c}+12.24(S D=8.38), \\
p<.001\end{array}$ & $\begin{array}{c}79.31 \\
(S D=9.26) \\
\text { at }+9 \text { months }\end{array}$ & $\begin{array}{c}+1.97(S D=7.27) \\
p=.112\end{array}$ & $\begin{array}{c}81.28 \\
(S D=11.96) \\
\text { at }+18 \text { months }\end{array}$ \\
\hline SA group 2 & $\begin{array}{c}71.41 \\
(S D=15.82) \\
\text { at +0 months }\end{array}$ & $\begin{array}{c}+7.76(S D=9.68) \\
p<.001\end{array}$ & $\begin{array}{c}79.18 \\
(S D=10.71) \\
\text { at }+3 \text { months }\end{array}$ & $\begin{array}{c}-0.49(S D=7.43) \\
p=.492\end{array}$ & $\begin{array}{c}78.79 \\
(S D=13.46) \\
\text { at +9 months }\end{array}$ \\
\hline AH group & $\begin{array}{c}67.75 \\
(S D=18.14) \\
\text { at }+0 \text { months }\end{array}$ & $\begin{array}{c}+7.20(S D=7.56) \\
p<.01\end{array}$ & $\begin{array}{c}74.95 \\
(S D=18.39) \\
\text { at }+9 \text { months }\end{array}$ & $\begin{array}{c}+0.24(S D=7.49) \\
p=.667\end{array}$ & $\begin{array}{c}75.19 \\
(S D=24.01) \\
\text { at }+18 \text { months }\end{array}$ \\
\hline
\end{tabular}

Notes. $S A=$ study abroad, $P R=$ post-return; range of possible scores on the C-test: 0 -100 
Students in SA group 1 had made significant gains of 12.24 points $(S D=8.38, p<.001$, Cohen's $d=0.56$ ) on the C-test on average during their academic year (nine months) abroad. This involved a sprint of 8.70 points $(S D=6.19, p<.001)$ on average during the first three months, and a more modest average gain of 3.54 points $(S D=5.51, p<.001)$ during the subsequent six months abroad. Students in the AH group had gained 7.20 points $(S D=7.56, p$ $<.01$, Cohen's $d=0.38$ ) on average during the same nine-month period of study at the home university, resulting in a significant advantage in progress of +5.04 points $(p<.05$, Cohen 's $d$ $=0.62$ ) on average for students in SA group 1 by the end of study abroad (at pre-return).

Students in SA group 2 had also made significant progress of 7.76 points $(S D=9.68, p<$ .001 , Cohen's $d=0.51$ ) on average during their three-month stay abroad. Compared to studying abroad for an entire academic year, overall L2 proficiency gains made during a single term abroad tended to be significantly lower at -4.48 points $(p<.05$, Cohen's $d=0.49)$ on average.

After the students' return to the home country, both the ERASMUS students who had studied in the UK for one academic year $(M=+1.97$ points, $S D=7.27, p=.112)$, and the students who had studied in the UK for one term only $(M=-0.49$ points, $S D=7.43, p=.492)$ tended to plateau in their overall L2 proficiency levels. Thus, returnees in SA groups 1 and 2 tended to sustain the overall L2 proficiency level they had built up abroad at +9 and +6 months, with most students neither experiencing significant progress nor regression in overall proficiency after their return to the home country. The difference in post-return development between students in the two SA groups was non-significant $(t(69)=1.60, p=.114)$, and the observed between-group effect not even small (Cohen's $d=0.23$ ). Similarly to the ERASMUS returnees, students in the $\mathrm{AH}$ group tended to experience neither significant regression nor progress in overall L2 proficiency during the 'post-return' phase $(M=+0.24$ points, $S D=7.49$, $p=.667)$. 


\subsection{Students' self-assessments of their English language skills at pre- and post-return}

Table 4 shows the students' assessments of their English reading, writing, listening and speaking skills in informal and academic contexts at baseline / pre-study abroad, by the end of study abroad / pre-return, and at the end of the observed post-return period. The selfassessment scale ranged from one (very limited) to seven (excellent). At baseline / predeparture, the students' self-assessments already tended to fall into the upper third of the scale, reflecting their profile as advanced English language learners. Students in all three groups tended to rate their reading skills in informal contexts highest and their academic writing and speaking skills the lowest. 
Table 4. Self-assessed L2 skills at pre-departure, pre-return and post-return

\begin{tabular}{lccc}
\hline Skill area & $\begin{array}{c}\text { Pre-departure } \\
\text { Mean } / S D\end{array}$ & $\begin{array}{c}\text { Pre-return } \\
\text { Mean } / S D\end{array}$ & $\begin{array}{c}\text { Post-return } \\
\text { Mean } / S D\end{array}$ \\
\hline SA group 1 & & & \\
Academic reading & $5.40 / 1.03$ & $\mathbf{5 . 8 6 / 0 . 9 4}$ & $\mathbf{5 . 5 4 / 1 . 0 7}$ \\
Academic writing & $4.14 / 1.19$ & $\mathbf{5 . 0 6 / 1 . 0 3}$ & $4.89 / 0.93$ \\
Academic listening & $5.46 / 0.87$ & $\mathbf{6 . 0 6 / 1 . 0 5}$ & $5.91 / 1.10$ \\
Academic speaking & $4.51 / 1.15$ & $\mathbf{5 . 2 9 / 1 . 1 0}$ & $5.29 / 1.13$ \\
Informal reading & $6.37 / 0.69$ & $6.40 / 1.06$ & $6.31 / 0.99$ \\
Informal writing & $5.57 / 1.20$ & $5.94 / 1.28$ & $5.86 / 1.06$ \\
Informal listening & $5.77 / 1.03$ & $6.00 / 1.16$ & $6.11 / 1.11$ \\
Informal speaking & $5.37 / 1.24$ & $5.71 / 1.25$ & $5.89 / 1.05$ \\
\hline SA group 2 & & & \\
Academic reading & $5.26 / 1.15$ & $\mathbf{5 . 7 7 / 0 . 8 4}$ & $5.71 / 0.86$ \\
Academic writing & $4.20 / 1.26$ & $\mathbf{4 . 9 7 / 1 . 0 7}$ & $4.89 / 0.96$ \\
Academic listening & $5.20 / 1.26$ & $\mathbf{5 . 8 0 / 0 . 9 9}$ & $5.69 / 0.99$ \\
Academic speaking & $4.27 / 1.37$ & $\mathbf{5 . 0 0 / 1 . 0 3}$ & $5.06 / 1.14$ \\
Informal reading & $6.00 / 1.13$ & $6.29 / 0.71$ & $6.17 / 0.75$ \\
Informal writing & $5.37 / 1.37$ & $5.83 / 0.92$ & $5.91 / 0.85$ \\
Informal listening & $5.37 / 1.40$ & $5.80 / 0.83$ & $5.94 / 0.84$ \\
Informal speaking & $4.80 / 1.35$ & $\mathbf{5 . 5 4 / 1 . 0 1}$ & $5.66 / 0.80$ \\
\hline AH group & & & \\
Academic reading & $5.58 / 0.90$ & $5.32 / 0.95$ & $5.32 / 1.11$ \\
Academic writing & $4.47 / 1.22$ & $4.53 / 0.96$ & $4.68 / 1.00$ \\
Academic listening & $6.00 / 0.88$ & $5.79 / 0.79$ & $5.68 / 1.00$ \\
Academic speaking & $4.84 / 1.57$ & $4.84 / 1.21$ & $5.11 / 1.10$ \\
Informal reading & $6.47 / 0.61$ & $6.47 / 0.51$ & $6.42 / 0.69$ \\
Informal writing & $6.00 / 0.88$ & $5.95 / 0.78$ & $5.95 / 0.71$ \\
Informal listening & $6.32 / 0.67$ & $6.32 / 0.67$ & $6.17 / 0.71$ \\
Informal speaking & $5.53 / 1.54$ & $5.63 / 1.01$ & $5.63 / 0.76$ \\
\hline
\end{tabular}

Note. Scale ranges from 1 (very limited) to 7 (excellent); significant changes in bold

By the end of study abroad, the students' ratings of their academic reading, writing, listening and speaking skills had significantly increased within both SA groups (all mean changes $p<$ .05 ), with the largest gains recorded in academic writing and speaking (both $p<.01$ ). The gains in these areas tended to be highly similar within both groups, despite the difference in length of stay, suggesting that gains in self-perceived L2 skills tended to occur mostly during the first term abroad. Students in SA group 2 also tended to rate their speaking skills in 
informal contexts higher at the end of their term abroad $(p<.05)$, which was not the case for students in SA group 1, presumably because the latter tended to have higher levels of selfperceived informal speaking skills at baseline (initial between-group difference $p<.05$ ).

During the post-return phase, no further significant changes were observable in any of the observed skill areas, except for a decline in self-assessed academic reading skills among students in SA group $1(p<.05$; very small effect Cohen's $d=0.31)$. The self-assessments of students within the AH group tended to remain unchanged during the 'study abroad' and the 'post-return' periods.

\subsection{Factors associated with overall L2 proficiency development post-return}

As discussed above, most students in each group neither showed significant progress nor regression in their overall English proficiency scores during the observed post-return phase. However, just under one third of the students in each group (32\% in SA group 1, 26\% in SA group 2, 28\% in the $\mathrm{AH}$ group) did make progress of five points or more on the C-test, while $11 \%$ of the students in SA group 1,22\% in SA group 2, and 18\% in the AH group regressed by five points or more. Thus, multiple regression analysis was carried out to examine what participant-related factors may be associated with such progression and regression post-return, including participant background characteristics (gender, studying English vs. another academic subject), length of stay abroad, factors pertaining to students' L2 proficiency and L2 self-conceptions (pre-return C-test score, students' self-conceptions of their English skills at pre-return, self-efficacy in conversing in English at pre-return), as well as factors pertaining to students' continued L2 contact (frequency of L2 usage during free time, amount of Englishmedium instruction [EMI] at university, proportion of course readings in English). 
Table 4. Individual differences factors examined

\begin{tabular}{|c|c|c|}
\hline Factor & Definition & Statistic \\
\hline Participant gender & Participant gender $[\mathrm{F}=0 ; \mathrm{M}=1]$ & $\begin{array}{l}\mathrm{B}=2.96, t(90)=1.61 \\
r=.17, p=.160\end{array}$ \\
\hline $\begin{array}{l}\text { English-major } \\
\text { vs. other subject studied }\end{array}$ & $\begin{array}{l}\text { Participant is (not) studying English as a major at } \\
\text { university }\end{array}$ & $\begin{array}{l}\mathrm{B}=3.61, t(90)=2.16 \\
r=.22, p<.05\end{array}$ \\
\hline $\begin{array}{l}\text { Participation in ERASMUS for } \\
\text { one term vs. one academic year }\end{array}$ & $\begin{array}{l}\text { Participant studied abroad with ERASMUS for one } \\
\text { academic year as opposed to one term }\end{array}$ & $\begin{array}{l}\mathrm{B}=2.28, t(90)=1.32 \\
\text { partial } r=.14, p=.217\end{array}$ \\
\hline $\begin{array}{l}\text { Pre-return overall L2 } \\
\text { proficiency level (C-test score) }\end{array}$ & $\begin{array}{l}\text { Overall L2 proficiency level (C-test score) achieved } \\
\text { by the participant at the end of study abroad }\end{array}$ & $\begin{array}{l}\mathrm{B}=0.16, t(90)=2.54 \\
r=.26, p<.05\end{array}$ \\
\hline $\begin{array}{l}\text { Pre-return composite score of } \\
\text { self-perceived L2 skills }\end{array}$ & $\begin{array}{l}\text { Participant's self-assessed L2 skills at pre-return } \\
\text { (composite of reading, writing, listening and } \\
\text { speaking in informal and academic contexts) }\end{array}$ & $\begin{array}{l}\mathrm{B}=0.66, t(91)=0.52 \\
\text { partial } r=-.11, p=.602\end{array}$ \\
\hline $\begin{array}{l}\text { Pre-return L2 self-efficacy } \\
\text { (using } L 2 \text { in conversation) }\end{array}$ & $\begin{array}{l}\text { Level of self-efficacy in using English in social } \\
\text { interactions achieved by the end of study abroad }\end{array}$ & $\begin{array}{l}\mathrm{B}=1.97, t(91)=3.21 \\
r=.32, p<.01\end{array}$ \\
\hline $\begin{array}{l}\text { Continued contact / use of } \\
\text { English during free time }\end{array}$ & $\begin{array}{l}\text { Frequency of using English in the participant's free } \\
\text { time: daily / several times per week / at least once a } \\
\text { week / occasionally / never }\end{array}$ & $\begin{array}{l}\mathrm{B}=0.68, t(79)=0.89 \\
\text { partial } r=.14, p=.372\end{array}$ \\
\hline $\begin{array}{l}\text { Continued contact / use of acad. } \\
\text { English: course readings }\end{array}$ & $\begin{array}{l}\text { Proportion of the participant's course readings in } \\
\text { English during observed post-return phase }\end{array}$ & $\begin{array}{l}\mathrm{B}=0.35, t(79)=1.27 \\
\text { partial } r=.17, p=.206\end{array}$ \\
\hline $\begin{array}{l}\text { Continued contact / use of acad. } \\
\text { English: English-medium } \\
\text { instruction (hours / week) }\end{array}$ & $\begin{array}{l}\text { Amount of weekly contact hours taught through } \\
\text { English (EMI) during observed post-return phase }\end{array}$ & $\begin{array}{l}\mathrm{B}=0.14, t(79)=0.61 \\
\text { partial } r=.16, p=.408\end{array}$ \\
\hline
\end{tabular}

As the results in Table 4 show, L2 proficiency level achieved by the end of study abroad $(p<$ $.05)$, pre-return levels of self-efficacy in using English in social interactions $(p<.01)$, and studying English as a major $(p<.05)$ emerged as significant predictors of L2 proficiency development post-return.

\section{L2 proficiency level achieved by the end of the study abroad period}

The students' pre-return C-test score was positively associated with L2 proficiency development post-return $(r=.26, p<.05)$. In other words, students who had achieved a higher overall L2 proficiency level by the end of the study abroad period were more likely to maintain or make progress and less likely to experience attrition in their overall L2 proficiency levels during the observed post-return period. The students' pre-return L2 proficiency level predicted post-return L2 proficiency maintenance and development over and above the actual length of stay abroad (partial $r=.26 ; p<.05$ ) and total L2 proficiency gain made during study abroad (partial $r=.21 ; p<.05$ ). 


\section{Self-efficacy in using English in social interactions}

Students' levels of self-efficacy in using English in social interactions (i.e., students' beliefs about their ability to converse in English) as measured at the end of study abroad were positively associated with L2 proficiency development post-return $(r=.32, p<.01)$. More efficacious students also tended to have higher actual pre-return L2 proficiency levels $(r=$ $.36 ; p<.01)$. However, self-efficacy still significantly predicted post-return L2 development (partial $r=.25, p<.05$ ) when students' actual L2 proficiency levels were controlled for. Prereturn self-efficacy in using the L2 in social interactions was also significantly correlated with students' overall self-assessment of their reading, writing, listening and speaking skills at prereturn $(r=.61, p<.001)$. When entered into the regression model together, only self-efficacy in using the L2 in social interactions was significantly associated with post-return L2 proficiency development $(r=.22, p<.05)$, while students' overall self-assessment of their L2 skills failed to predict proficiency development (partial $r=.06, p=.602$ ). Students' pre-return levels of L2 self-efficacy in using English in social interactions also significantly predicted students' continued post-return L2 usage in their free time $(r=.31, p<.01)$, while students' self-reported L2 contact / usage itself failed to predict post-return L2 proficiency development.

\section{Continued L2 contact / usage post-return}

In order to gauge how frequently students were still using English after their return from SA, the post-return questionnaire asked "How often, if at all, do you use English in your free time?" ("Wie oft, falls überhaupt, verwenden Sie Englisch in Ihrer Freizeit?”). Table 5 summarizes the responses of students in all groups. Within both SA groups, the majority of returnees reported using English at least several times per week. However, the number of students who chose to use English on a daily basis was more than twice as high within SA group 1, while the number of students who chose to use English occasionally or almost never 
was more than twice as high in SA group 2. Whether these preferences are an outcome of participation in SA cannot be ascertained as this would warrant a comparison with students' pre-SA usage patterns. Students in the AH reported to be the most eager L2 users, with $88 \%$ of the respondents using English at least several times per week. This may be a reflection of the high levels of L2 self-motivation and/or anglophilia among the rejected / withdrawn applicants who chose to join the study, or potentially a perceived need to compensate for the lack of opportunity to study abroad in an English-speaking country.

Table 5. Frequency of students' continued L2 usage in their free time $[N(\%)]$

\begin{tabular}{lccc}
\hline & SA group 1 & SA group 2 & AH group \\
\hline$\ldots$ on a daily basis & $11(28.2 \%)$ & $5(12.8 \%)$ & $11(44.0 \%)$ \\
\hline $\begin{array}{l}\text {.. several times } \\
\text { per week }\end{array}$ & $16(41.0 \%)$ & $19(48.7 \%)$ & $11(44.0 \%)$ \\
\hline$\ldots$ about once per & $3(6.7 \%)$ & $3(7.8 \%)$ & $3(12.0 \%)$ \\
week & & & $0(0.0 \%)$ \\
\hline$\ldots$ occasionally & $5(12.8 \%)$ & $11(28.2 \%)$ & $0(0.0 \%)$ \\
\hline$\ldots$ almost never & $4(10.3 \%)$ & $1(2.6 \%)$ & \\
\hline
\end{tabular}

When asked in what contexts the students were using English in their free time, they reported reading books and/or articles (digital or in print) as the most commonly pursued activity, followed by consuming movies, series and radio programmes, using English on Facebook and other social media, writing e-mail messages in English, and speaking English with friends. This order was reflected in all three groups. Using English on gaming platforms, with ERASMUS buddies, and with family members were further isolated nominations.

With regard to students' contact with English at the home university during the observed post-return phase, it was assumed that patterns of contact may differ between English majors and non-majors. Thus, these sub-groups are differentiated in Tables 6 and 7. Table 6 shows that the amount of weekly EMI varied quite strongly within groups. Moreover, in both SA groups English majors tended to report higher amounts of weekly EMI classes 
than their peers studying other subjects. Comparing the non-majors between groups, nonmajors in the AH group tended to choose a higher number of weekly EMI hours than students who had participated in SA (all between-group differences significant at $p<.05$ level).

Table 6. Average number of weekly course contact hours taught through English (EMI)

\begin{tabular}{llll}
\hline & SA group 1 & SA group 2 & AH group \\
\hline Non-majors & $\mathrm{M}=2.68$ & $\mathrm{M}=2.03$ & $\mathrm{M}=4.11$ \\
& $(\mathrm{SD}=4.26)$ & $(\mathrm{SD}=4.00)$ & $(\mathrm{SD}=5.51)$ \\
\hline English majors & $\mathrm{M}=4.58$ & $\mathrm{M}=6.70$ & $\mathrm{M}=5.14$ \\
& $(\mathrm{SD}=3.29)$ & $(\mathrm{SD}=5.30)$ & $(\mathrm{SD}=1.95)$ \\
\hline
\end{tabular}

Table 7 shows further that even among the non-majors, over $75 \%$ of the participants reported that at least some of their course readings were in English. Thus, the clear majority of students continued to have contact with academic English on a regular basis, which is both a reflection of the students' preferences and the increasing spread of English in higher education.

Table 7. Students who reported having course readings in English [N(\%)]

\begin{tabular}{llll}
\hline & SA group 1 & SA group 2 & AH group \\
\hline Non-majors & $21(80.8 \%)$ & $24(77.4 \%)$ & $15(83.3 \%)$ \\
& $($ overall $N=26)$ & $($ overall $N=31)$ & $($ overall $N=18)$ \\
\hline English majors & $12(85.7 \%)$ & $9(90 \%)$ & $7(100 \%)$ \\
& $($ overall $N=14)$ & $($ overall $N=10)$ & $($ overall $N=7)$ \\
\hline
\end{tabular}

Neither the frequency of students' self-reported L2 usage during their free time (partial $r$ $=.14, p=.372$ ), the amount of EMI at university (partial $r=.16, p=.408$ ), nor the amount of academic course readings in English (partial $r=.17, p=.206$ ) significantly predicted postreturn L2 proficiency maintenance and development. Participation in English language classes post-return could not be tested as a predictor due to insufficient variation in this variable.

Only one student in SA group 1, two students in SA group 2 and six students in the AH group 
participated in English languages classes post-return (one student in SA group 2 and three students in the AH group were English majors).

\section{Studying English as a major}

Majoring in English was also positively associated with overall L2 proficiency development post-return $(r=.22, p<.05)$. Against the general plateauing pattern, English majors in SA group 1 tended to make continued progress post-return $(M=+3.54$ points, $S D=3.90, p<$ .05). In contrast, within SA group 2 and the $\mathrm{AH}$ group the trend towards further progression among English majors did not reach significance (SA group 2: $M=+2.70$ points, $S D=5.12, p$ $=.130 ;$ AH group: $M=+2.71, S D=5.74, p=.207)$.

\subsection{ERASMUS students' perceived needs regarding further English language classes}

In order to gauge the returnees' perceived needs and interests regarding English language classes for further improving their L2 skills, the pre-return questionnaire for SA groups 1 and 2 asked: "What content and level would a language course of your choice have?" ("Welche Inhalte und welches Niveau hätte Ihr Wunschsprachkurs?") followed by an open response item. An alternative response option was "I would no longer consider participating in English language instruction." ("Ich würde keinen englischen Sprachkurs mehr in Betracht ziehen.").

Within SA group 1, those who had studied abroad for one academic year, $60.8 \%$ of students expressed interest in further English language instruction and made suggestions for content that they would find helpful following their study abroad experience, while as many as $70.7 \%$ of students in SA group 2 were interested in attending English language classes to further improve their English. Significantly, the students' suggestions tended to be more similar than different across the two groups, focusing on English academic writing and speaking, subject-specific language, English for professional purposes, and general conversational English at an advanced level. Further to this, the students were interested 
specifically in improving their use of idioms and idiomatic language, in reviewing grammar points, and in targeted assistance with their personal fossilized patterns of language use, both structurally and in terms of improving their pronunciation. The full list of suggestions is included in Appendix C.

\section{Discussion}

The present study is the first larger longitudinal inquiry into how ERASMUS students who study a variety of academic subjects and are not necessarily language specialists maintain and further develop overall L2 proficiency following participation in ERASMUS study abroad programmes lasting one term or one academic year.

The testing component of the study showed that ERASMUS returnees in both groups tended to maintain the gains in overall L2 proficiency made abroad without showing significant progress or attrition in their overall L2 proficiency levels at +6 and +9 months post-return (RQ 1). In contrast to previous studies observing successful maintenance of overall L2 proficiency among study abroad returnees (e.g., Juan-Garau, Salazar-Noguera, \& Prieto-Arranz, 2014), the vast majority of students in the present study did so without attending any further English language classes. However, most study participants were still exposed to English through EMI and/or course readings in English. The differences in postreturn L2 proficiency development between students who had studied abroad for one term as compared to one academic year were non-significant. Thus, while ERASMUS participants on shorter exchanges tended to make lower overall L2 proficiency gains abroad (also see Hessel \& Vanderplank, 2018), statistically speaking they were no more likely to experience regression or progress in their overall L2 proficiency levels than their peers who had been on longer exchanges. Similarly to the SA returnees in both groups, the overall L2 proficiency levels of ERASMUS applicants who had continued to study at home tended to plateau in their overall L2 proficiency during the observed post-return phase. 
Consistent with the plateauing patterns observed in the testing component of the study, the students' self-ratings of their English reading, writing, listening and speaking skills in informal and academic contexts tended to remain unchanged from pre-return to post-return within all three groups (RQ 2). The only exception was a significant decline in self-assessed academic reading skills among students in SA group 1 at +9 months post-return. Based on the data collected, it is not clear why this decline in self-perceived academic reading skills would affect the longer-term abroad group only as, for example, there was no statistically significant difference in the amount of academic reading in English that returnees in both SA groups reported to undertake post-return. In contrast to academic reading skills, the increases in selfassessed academic writing, speaking and listening skills that were observable during the study abroad phase tended to be sustained by returnees in both groups. The fact that the selfassessments of students in the AH group tended to remain unchanged during the study abroad and post-return phases suggests that participation in ERASMUS study abroad tended to have positive effects on students' L2 self-conceptions in these domains that tended to last beyond their immediate return to the home country.

The study also investigated factors associated with individual differences in overall L2 proficiency development post-return (RQ 3). L2 proficiency level achieved by the end of study abroad (pre-return), students' self-efficacy in using English in social interactions at prereturn, and studying English as a major were all significantly and positively associated with post-return L2 proficiency development while participant gender, length of stay abroad, and extent of continued L2 contact / usage failed to reach significance.

Higher pre-return L2 proficiency levels had previously been associated with better maintenance of speech fluency and oral proficiency among MFL students of Spanish and French four years after the year abroad (Huensch et al., 2019), as well as with better maintenance of speech fluency and lexical diversity twelve months post-return from 
ERASMUS study abroad (Mehotcheva, 2010). Thus, there is cumulative evidence that students achieving higher L2 proficiency levels by the end of study abroad maintain their oral and overall L2 proficiency levels better upon return. Studies that involve SA participants with lower pre-return proficiency levels are needed to further examine whether a certain proficiency threshold may need to be crossed in order to confer advantages for post-return L2 maintenance and development.

In view of questions regarding the relative importance of pre-return proficiency levels and continued L2 contact / usage in post-return L2 maintenance (raised, for example, in Huensch et al., 2019), the present study finds that pre-return L2 proficiency levels were significantly associated with successful maintenance of overall L2 proficiency for the advanced learners under study while frequency and amount of continued L2 contact in the students' free time and in their academic work were not. Provided that this does not reflect a self-report issue (i.e., the accuracy with which the students reported using English after their return from SA), this result suggests that frequency and amount of continued L2 contact were less pertinent for maintaining overall L2 proficiency levels for the advanced learners under study. It may also highlight the need for observing other aspects of L2 contact. For example, students' use of English in their free time was captured in terms of frequency, but the qualities of these instances of use, such as the students' affective engagement, were not captured. It is conceivable that the qualities of continued L2 contact / usage may bear a stronger relationship with post-return L2 proficiency development than its frequency and amount.

Beyond students' pre-return L2 proficiency levels, their pre-return levels of self-efficacy in using the L2 in social interactions were also positively associated with post-return L2 development, while students' overall self-assessment of their L2 reading, writing, listening and speaking skills had no predictive power. Thus, students' conceptions of how well they were able to converse in the L2 seemed to be particularly important in relation to L2 
proficiency maintenance and development post-return. In explaining this relationship, social cognitive theory (Bandura, 1986) would predict that more efficacious students will be more confident and inclined to use the L2 in social interactions when such opportunities arise, which may be conducive to L2 maintenance and development. Consistent with this argument, self-efficacy in using the L2 in social interactions was indeed significantly associated with the frequency of self-reported L2 usage in the students' free time. However, given that selfreported L2 usage itself had such limited predictive power, one may also hypothesize on the significance of the increased psychological value of L2 skills in itself. Students who regard themselves as more proficient L2 speakers after having studied abroad may consider their L2 skills as more central to their overall self-concept as a person, and assign more importance to their maintenance and development (Mercer, 2012). While the dynamics of this relationship will need to be further illuminated in qualitative studies, the current study draws attention to the predictive power of students' self-conceptions as proficient L2 speakers, including their perceived ability to express themselves in authentic ways, as a factor in L2 proficiency maintenance and development post-study abroad.

Lastly, majoring in English was also positively associated with overall L2 proficiency development post-return. Against the general plateauing pattern, English majors in group 1 tended to show further progress on the C-test post-return. In contrast to the foreign language majors involved in previous post-return studies, none of the English majors in SA group 1 attended English language classes post-SA. However, they reported a higher average amount of weekly course contact hours taught in English (EMI) than their peers studying other subjects (4.6 vs. 2.7 hours per week on average). In contrast to SA group 1, the plateauing pattern observed among English majors in the shorter-term SA group 2 is in line with JuanGarau, Salazar-Noguera, and Prieto-Arranz (2014), who also observed a plateau in overall L2 proficiency with their English majors after a three-month ERASMUS exchange in the UK. 
And yet, there are important contextual differences between the two studies as 1) all of their English majors received an additional 80 hours of English language classes post-SA, and 2) the post-return observation period was considerably longer with +15 instead of +6 months. Significantly, the finding of the present study that English majors on longer ERASMUS exchanges tended to make further progress while their peers studying other subjects did not, provides some indication that post-return development observed with MFL students may not be readily generalizable to the wider ERASMUS student population. Thus, more post-return studies involving students not specializing in languages are urgently needed.

The finding that gains in overall L2 proficiency made during study abroad tended to be successfully maintained at +6 and +9 months post-return, even by ERASMUS study abroad participants who do not study the L2 at degree-level is rather encouraging. At the same time, the observed plateauing pattern suggests that further progress at the advanced level would in most cases require stronger facilitation through the students' home institutions. Thus, the creation of learning programmes that support returning study abroad participants in further developing their L2 proficiencies in an independent manner and/or instructed settings is highlighted as an area for institutional development. It is hoped that the appended list of the returnees' perceived needs and interests in this regard may be of help in informing such efforts.

\section{Limitations and suggestions for future work}

Linguistically speaking, the present study is limited in scope as the C-test provides a valid indication of students' overall L2 proficiency levels but does not permit conclusions regarding L2 development in specific skill areas. It is possible therefore that the participants tended to maintain their overall L2 proficiency levels, but would show signs of attrition in aspects of their oral fluency, as found in Mehotcheva's (2010) multiple case study. Thus, there is a need for further studies into more specific areas of L2 knowledge and skills development with 
returning ERASMUS students. Regardless of the test construct(s) employed, the results of such extended longitudinal studies need to be interpreted with caution as the stronger students on the panel may be more willing to participate in a delayed post-test, thus painting a more optimistic picture of post-SA L2 development than would have been found with a complete sample. If the same test is employed repeatedly, practice effects may add further to such positivity bias. The inclusion of a comparison group as in the current study can effectively control for such practice effects.

Despite its limitations, the present study contributes to charting the post-return phase of study abroad with initial insights into L2 proficiency maintenance and development among returning ERASMUS students who have diverse academic subject backgrounds and are not necessarily Foreign Language Majors. It also examined a number of participant-related factors in relation to individual differences in post-return L2 development. Its results show that gains in overall L2 proficiency made by students on ERASMUS exchanges lasting either one term or one academic year tended to be maintained at +6 and +9 months post-return respectively, and in the clear majority of cases without attending further English language classes. Due to the low numbers of students attending such classes, their role and significance as a factor in post-return L2 proficiency development could not be tested. This is an area for future work with important implications for supporting continued L2 skills development among returning students.

The participants in the present study reported fairly high levels of continued L2 contact after their return to the home country both in their free time and in the context of their academic work. To some extent, this is a reflection of the increasing spread of English as a medium of instruction at European universities (Wächter \& Maiworm, 2014). These high levels of L2 contact did not tend to be sufficient for further progress in overall L2 proficiency. The lack of a significant association suggests further that continued L2 contact was not a 
crucial variable in successful L2 maintenance for the advanced learners under study. Future studies that investigate post-return L2 maintenance and development with learners of languages other than English (LOTEs) would provide an interesting point of comparison as L2 contact in the home country would presumably be less abundant. Thus, they may further illuminate the role of L2 proficiency level achieved by the end of SA in warding off attrition when L2 contact is less frequent.

In the present study, the level of L2 proficiency achieved by the end of study abroad, selfefficacy in using the L2 in social interactions (conceiving of the self as a competent L2 speaker) and majoring in the L2 emerged as significant variables in the successful maintenance of overall L2 proficiency. Both qualitative and quantitative studies are needed to further investigate these and other factors that may be involved in L2 development post-SA, such as returnees' cognitive abilities, L2 self-concept and self-motivation, attitudes and beliefs related to L2 learning, self-regulation and strategic L2 learning behaviour. Moreover, the role of length of stay as a factor in post-SA L2 maintenance and development warrants further examination in relation to all areas of L2 knowledge and skills. Lastly, given cumulative evidence for the involvement of pre-return proficiency level achieved, there is an urgent need to conduct studies with returning study abroad participants below the advanced level, including their perceived L2 learning needs, and factors that may impede or enable continued L2 progress post-return.

\section{Acknowledgements}

This study was funded by FWF (Austrian Science Fund) grant number M2353-G29. The author would also like to thank the editor, the anonymous reviewers, Sarah Mercer, Robert Vanderplank, and Apostol Qendro for their very helpful feedback on earlier versions of this manuscript. 


\section{References}

Asano, Y. (2014). Misst ein C-Test das, was er messen soll? In R. Grotjahn (Ed.). Language Testing and Evaluation, Volume 34: Der C-Test / The C-Test : Aktuelle Tendenzen / Current Trends (pp. 76-98). Frankfurt/ Main: Peter Lang.

Babaii, E., \& Ansary, H. (2001). The C-test: a valid operationalization of reduced redundancy principle? System, 29(2), 209-219. https://doi.org/10.1016/S0346-251X(01)00012-4

Bandura, A. (1986). Social foundations of thought and action: A social cognitive theory. Englewood Cliffs, NJ: Prentice-Hall.

Beattie, J., Valls-Ferrer, M., \& Pérez-Vidal, C. (2014). Listening performance and onset level in formal instruction and study abroad. In C. Pérez-Vidal (Ed.). Second language acquisition in study abroad and formal instruction contexts, AILA Applied Linguistics Series Volume 13 (pp.195-216). Amsterdam/ Philadelphia: John Benjamins Publishing Company. https://doi.org/10.1075/aals.13.10ch8

Davidson, D. E. (2010). Study abroad: When, how long, and with what results? New data from the Russian front. Foreign Language Annals, 43(1), 6-26.

Dörnyei, Z., \& Katona, L. (1992). Validation of the C-test amongst Hungarian EFL learners, Language Testing, 9, 187-206. https://doi.org/10.1177/026553229200900206

Eckes, T., \& Grotjahn, R. (2006). A closer look at the construct validity of C-tests. Language Testing, 23(3), 290-312. https://doi.org/10.1191/02655322061t330oa

Efron, B., \& Tibshirani, R. J. (1993). An Introduction to the bootstrap. New York: Chapman \& Hall. https://doi.org/10.1007/978-1-4899-4541-9

Engel, L., Sandstrom, A.-M., Van der Aa, R., \& Glass, A. (2015). The EAIE Barometer: Internationalisation in Europe. Amsterdam: European Association for International Education (EAIE).

European Commission (2014). ERASMUS+ Programme Guide (Version 2). Brussels: Directorate General Education and Culture.

European Commission (2015). ERASMUS - Facts, figures \& trends. The European Union support for student and staff exchanges and university cooperation in 2013-2014. Luxembourg: Publications Office of the European Union

Field, A. (2013). Discovering statistics using SPSS (4th ed.). Thousand Oaks, CA: Sage. 
Grotjahn, R. (2010). Der C-Test: Beiträge aus der aktuellen Forschung. Einleitung und Übersicht über den Band. In R. Grotjahn (Ed.). The C-Test: Contributions from Current Research (pp. viiii-xxix). Frankfurt/Main: Peter Lang.

Grotjahn, R. (2014). Der C-Test: Aktuelle Tendenzen The C-Test: Current Trends. Frankfurt/Main: Peter Lang GmbH. https://doi.org/10.3726/978-3-653-04578-9

Hessel, G. (2016). The impact of study abroad in the UK on students' overall English proficiency, self-efficacy, English use anxiety and self-motivation to continue learning English: a mixed methods investigation (Unpublished doctoral thesis). University of Oxford/ St Edmund Hall, Oxford, UK.

Hessel, G. (2017). A new take on individual differences in L2 proficiency gain during study abroad. System, 66, 39-55. DOI: 10.1016/j.system.2017.03.004.

Hessel, G. (2019). Study Abroad: L2 Self-efficacy and Engagement in Intercultural Interactions. In A. Kostoulas (Ed.). Challenging Boundaries in Language Education (pp. 199-210). Basel: Springer.

Hessel, G., \& Vanderplank, R. (2018). What difference does it make? Examining English proficiency gain as an outcome of participation in ERASMUS study abroad programmes in the UK. Study Abroad Research in Second Language Acquisition and International Education, 3(2), 191-219. DOI: 10.1075/sar.16020.hes

Howard, M. (2009). Short- versus long-term effects of naturalistic exposure on the advanced instructed learner's L2 development: A case study. In E. Labeau \& F. Myles (Eds.). The advanced learner varieties: The case of French (pp. 93-123). Bern: Peter Lang.

Huensch, A., \& Tracy-Ventura, N. (2017). L2 utterance fluency development before, during, and after residence abroad: A multidimensional investigation. The Modern Language Journal, 101, 275-293. https://doi.org/10.1111/modl.12395

Huensch, A., Tracy-Ventura, N., Bridges J., \& Cuesta Medina, J. A. (2019). Variables affecting the maintenance of L2 proficiency and fluency four years post-study abroad. Study Abroad Research in Second Language Acquisition and International Education, 4(1), 97-126. https://doi.org/10.1075/sar.17015.hue

Ife, A., Vives, G., \& Meara, P. (2000). The impact of study abroad on the vocabulary development of different proficiency groups. Spanish Applied Linguistics, 4(1), 55-84.

Juan-Garau, M. (2014). Oral accuracy growth after formal instruction and study abroad. In C. Pérez-Vidal (Ed.). Second language acquisition in study abroad and formal instruction 
contexts, AILA Applied Linguistics Series Volume 13 (pp.87-110). Philadelphia: John Benjamins Publishing Company. https://doi.org/10.1075/aals.13.12ch10

Juan-Garau, M., Salazar-Noguera, J., \& Prieto-Arranz, J. I. (2014). English L2 learners' lexico-grammatical and motivational development at home and abroad. In C. Pérez-Vidal (Ed.). Second language acquisition in study abroad and formal instruction contexts, AILA Applied Linguistics Series Volume 13 (pp.235-258). Amsterdam/ Philadelphia: John Benjamins Publishing Company.

Keijzer, M. (2007). Last in first out? An investigation of the regression hypothesis in Dutch emigrants in Anglophone Canada. LOT dissertation series Nr. 163. Retrieved from https://www.lotpublications.nl/last-in-first-out-last-in-first-out-an-investigation-of-theregression-hypothesis-in-dutch-emigrants-in-anglophone-canada

Khabbazbashi, N. (2013). An Investigation into the Effects of Topic and Background Knowledge of Topic on Second Language Speaking Performance Assessment in Language Proficiency Interviews (Unpublished doctoral thesis). Oxford University/ Worcester College, Oxford, UK.

Kubota, M. (2017). Post study abroad investigation of kanji knowledge in Japanese as a second language learners. System, 69, 143-152.

Kuckartz, U. (2012). Qualitative Inhaltsanalyse. Methoden, Praxis, Computerunterstützung. Basel: Beltz Juventa.

Llanes, À. (2012). The short-and long-term effects of a short study abroad experience: The case of children. System, 40(2), 179-190.

Llanes, A., \& Muñoz, C. (2009). A short stay abroad: Does it make a difference? System, 37(3), 353-365.

Leiner, D. J. (2019). SoSci Survey (Version 3.1.06) [Computer software]. Available at https://www.soscisurvey.de

Mehotcheva, T. H. (2010). After the fiesta is over: Foreign language attrition of Spanish in Dutch and German Erasmus students (Unpublished doctoral dissertation). University of Groningen, Groningen, The Netherlands.

Mercer, S. (2012). The dynamic nature of a tertiary learner's foreign language self-concepts. In M. Pawlak (Ed.). New perspectives on individual differences in language learning and teaching (pp. 201-215). Berlin Springer. https://doi.org/10.1007/978-3-642-20850-8_13 
Miles, J., \& Shevlin, M. (2001). Applying regression and correlation: A guide for students and researchers. Thousand Oaks, US: Sage.

Mitchell, R., Tracy-Ventura, N., \& McManus, K. (2017). Anglophone students abroad: Identity, social relationships and language learning. New York, NY: Routledge. https://doi.org/10.4324/9781315194851

Pérez-Vidal, C. (2014) Study abroad and formal instruction contrasted: The SALA project. In C. Pérez-Vidal (Ed.). Second language acquisition in study abroad and formal instruction contexts, AILA Applied Linguistics Series Volume 13 (pp. 17-58). Amsterdam/ Philadelphia: John Benjamins Publishing Company. https://doi.org/10.1075/aals.13.03ch2

Pérez-Vidal, C., \& Barquin, E. (2014). Comparing progress in academic writing after formal instruction and study abroad. Second language acquisition in study abroad and formal instruction contexts. In C. Pérez-Vidal (Ed.). Second language acquisition in study abroad and formal instruction contexts, AILA Applied Linguistics Series Volume 13 (pp. 217-234). Amsterdam/ Philadelphia: John Benjamins Publishing Company.

Pérez-Vidal, C., \& Juan-Garau, M. (2009). The effect of study abroad on written performance. Eurosla Yearbook, 9, 269-295. https://doi.org/10.1075/eurosla.9.13per

Pizziconi, B. (2017). Japanese vocabulary development in and beyond study abroad: the timing of the year abroad in a language degree curriculum. The Language Learning Journal, 45(2), 133-152.

Raatz, U., \& Klein-Braley, C. (1982). The C-test - a modification of the cloze procedure. In T. Culhane, C. Klein-Braley \& D. K. Stevenson (Eds.). Practice and problems in language testing IV (pp. 113-138). Colchester: University of Essex, Dept. of Language and Linguistics.

Rees, J., \& Klapper, J. (2007). Analysing and evaluating the linguistic benefit of residence abroad for UK foreign language students. Assessment and Evaluation in Higher Education, 32(3), 331-353. https://doi.org/10.1080/02602930600801860

Regan, V. (1995). The acquisition of sociolinguistic native speech norms. In B. F. Freed (Ed.). Second language acquisition in a study abroad context (pp. 245-267). Amsterdam: John Benjamins. https://doi.org/10.1075/sibil.9.15reg 
Sasaki, M. (2009). Changes in English as a Foreign Language students' writing over 3.5 years: A sociocognitive account. In R. Manchon (Ed.). Writing in foreign language contexts: Learning, teaching, and research (pp. 49-76). Clevedon: Multilingual Matters.

Sax, K. (2003). Acquisition of stylistic variation by American learners of French (Unpublished doctoral dissertation). Indiana University, Bloomington, IN.

Singleton, D., \& Singleton, E. (2002). The C-Test and L2 acquisition/processing research. In J.A. Coleman, R. Grotjahn \& U. Raatz (Eds.). University language testing and the C-test (pp. 143-168). Bochum: AKS-Verlag.

Spolsky, B. (1981). Some ethical questions about language testing. In C. Klein-Braley and D. K. Stevenson (Eds.). Practice and problems in language testing 1 (pp. 186 - 213). Frankfurt/Main: Peter Lang.

Valls-Ferrer, M., \& Mora, J. C. (2014). L2 fluency development in formal instruction and study abroad: The role of initial fluency level and language contact. In C. Pérez-Vidal (Ed.). Second language acquisition in study abroad and formal instruction contexts, AILA Applied Linguistics Series Volume 13 (pp. 111-136). Amsterdam/ Philadelphia: John Benjamins Publishing Company. https://doi.org/10.1075/aals.13.07ch5

Van Mol, C., \& Timmerman, C. (2014). Should I stay or should I go? An analysis of the determinants of intra-European student mobility. Population, Space and Place, 20(5), 465479. https://doi.org/10.1002/psp.1833

Vande Berg, M., Connor-Linton, J., \& Paige, R. M. (2009). The Georgetown Consortium Project: Interventions for student learning abroad. Frontiers: The Interdisciplinary Journal of Study Abroad, XVIII, 1-76.

Wächter, B., \& Maiworm, F. (Eds.). (2014). English-taught programmes in European higher education: The state of play in 2014. Bonn: Lemmens.

\section{Author's address:}

Gianna Hessel

Department of English Studies

University of Graz

Liebiggasse 9/HP

8010 Graz 
Austria

gianna.hessel@uni-graz.at 